\title{
Preface to 'The Ape Men of Mobongu'
}

\author{
Russell McDougall
}

$\mathrm{T}$ Twelve years ago, when 1 was putting together Short Stories 1925-1934 by Xuvier Herbert: South of Capricornia (Oxford, 1990), I discovered a fragment of an introductory chapter written in April 1979 for a planned but unpublished sequel to his autobiography. It took up the story from where Disturbing Element ends, w'ith his arrival in Sydney in 1926, which marked the real beginning of his literary career. In Melbourne before that he had published only one story. ${ }^{1}$ He was twenty-five and had come to Sydney to write. He was poor, his stories when they were accepted earned little, and he was writing paragraphs as 'Soda' for Smith's Weekly. Money was constantiy on his mind, and he chased every opportunity. In the fragment of autobiography I learned that he had written stories for 'a magazine for boys'.

'The Sea Vultures' was not difficult to find and I included it in South of Capricornia. It appeared originally in two instalments over two weeks in Pals: An Australian Paper for Australian Boys, which was published by the Melbourne Herald and Weekly Times. ${ }^{3}$ But although I hunted through a great variety of other boys' magazines. I could find no further trace of Herbert's children's writing until recently, when I had occasion to scour a Sydney magazine published by the Daily Telegraph from April 1926 to December 1927, The Boy's Weckly. There I found 'The Apes of Mobongu', by Herbert Astor.

It was not until mid-1933 that Alfred Herbert took the name by which he is now best known as the author of Capricornia (1938) and Poor Fellow My Country (1972). As Herbert Astor he published at least twelve stories, ten of them in the Australian Journal, between July 1926 and June 1929. They were popular romance and Boys' Own adventure stories written for mass magazine consumption, for money and for the pleasure of seeing one's name in print rather than from any great literary ambition. Yet 'The Ape-Men of Mobongu' is a remarkable find for a number of reasons. First, it is not referenced in any bibliography and receives no mention in the existing biography of Herbert. Second, in an oeuvre comprising approximately fifty published stories, it is one of only two known stories he wrote for children. (Published in the same year (1927), and composed more or less at the same time, 'The Sea Vultures' and 'The Ape-Men of
Mobongu' are twins.) Third, it is especially revealing in relation to his later writings on race. Fourth, it is one of only two stories set in Melanesia. (The Other McLean', published in November 1928, is set in the Solomon Islands.) And fifth, it has an interesting connection to his last known work, 'Billygoat Hill', which remains unpublished.

'The Ape-Men of Mobongu', like 'The Sea Vultures', is a rescue fantasy. 'The Sea Vultures' centres upon a boy's search for his father, abducted by a gang of criminals during a voyage to Singapore. Astor's re-invention of Fu Manchu as The Vulture provided the nightmare image, White Australia's worst fear of Asian invasion-a Chinese 'fiend', with thin serpent's lips, beaked nose, wrinkled yellow skin, long fingers with nails like claws and the power of both hypnotism and paralysis-inducing drugs at his disposal. In 'The Ape-Men of Mobongu', however, a colony of ape-men substitutes for the Asian triads; and the captivity narrative moves from Singapore to the Hidden River in Dutch New Guinea.

As Robert Dixon argues, captivity narratives in Australia not only were instrumental in shaping fictional representations of colonization, but also in shaping public representations of real events . . '(1995, p.46). Usually these events focused the conflict between Aboriginal people and white settlers. The New Guinea locale was partly inspired by Herbert's half-brother, Peter, who had gone to New' Guinea in mid-1926 to join the Government's Secretary's Department. But a more pertinent context for his choosing to set a captivity narrative in New Guinea is Australia's emergent sub-imperial role in the Pacific. Australia had enjoyed control over Papua (formerly British New Guinea) since 1906, and the League of Nations mandate of 1920 brought the German territory also under Australian administration. But Western or Dutch New Guinea, because it was outside Australia's jurisdiction, was necessarily a wilder frontier; and the Sepik particularly had entered imagination as home to barbarous headhunters and bloodthirsty cannibals. ${ }^{4}$ Nigel Krauth has noted the emergence in the 1920 s of a group of writersamong them Jack McLaren, G. Munro Turnbull, Alys Brown and lon Idriess-who 'began to see in representation of the Papuan and New Guinean villagers' 
outlook a means to viewing and assessing the Australian presence' (1982, p.xiv). Herbert knew virtually nothing about New Guinea or its peoples, and 'The Ape-Men of Mobongu' shows no educative conscience. Its sits more comfortably among the more outrageous nationaggrandizing romances' (ibid.) of the other pulp writers of the period, among whom Krauth singles out J.M. Walsh for his depictions of Australians as invincible supermen' in New Guinea (ibid). It may be worth asking why Herbert sets the story twelve years back from the time of its composition, in 1915, the baptismal year of the nation according to ANZAC legend.

At the time of 'The Sea Vultures' and 'The Ape-Men of Mobongu' Herbert must also have been working on his first extended adult fiction. 'Giants of Iron' was never published: and it survives now only as fragments of a discontinuous typescript. ${ }^{5}$ It was an imaginative rehearsal, really, for his intended journey around the Top End and back to his birthplace in Geraldion. He had come to believe that 'Australians are frontiersmen'. "Paradoxically, most Australian readers knew nothing of the nation's frontier. So that is where he would set the novel. He wanted it to stand as a social document. Pals urged its young male readers to uphold the cherished Empire values, and to have nothing to do with Aboriginals. They were 'a miserable specimen of humanity'. They were dirty, they speared cattle-they were not really British. 'The Sea Vultures' avoided Aboriginals and made the villain Oriental. 'Giants of Iron' also avoided the Aboriginal 'idea'. Its indigenous characters were cardboard cut-out caricatures. But in 'The Ape-Men of Mobongu' Herbert adopled a strategy of displacement rather than avoidance, projecting Australia's heart of darkness into New Guinea and placing the lost race there. Ape-men have long been figures of folklore and were favourites of early film. Sinbad's voyages took him to the Island of Apes, and Herbert may also have known A. Lee Knight's The Rajah of Monkey lsland (1906). Certainly he was fascinated by hybrid creatures-the goat with the fish tail, the half-man half-ape-and he firted throughout his career with the theme of the Lost Race. But it was Nietzsche who spoke the truth to Herbert: 'What is the Ape to Man? / A jest, a thing of shame! / So shall man be Superman.' The ape was an image of human counterfeit or lack. Years later, in his mid-fifties, when he became obsessed with advancing the human species, he toyed with a sequel to Solders' Women entitled 'What is the Ape to Man?' He dabbled in ethnology and sociobiology, explored his own behaviors and emotions in a postFreudian light. Humanity for Herbert was a matter of degree, and its measure was always the ancestor ape. Being a Hairy Man bolstered his masculinity but worried his humanity, for it was the sign of the hominid, or the pre-human. But 'The Ape-Men of Mobongu' marks the only literal appearance of the type in his writing. Quasimysterious 'spirit-giants', Herbert's ape-men are 'the souls of monkeys which men have killed, come back to the world for revenge'. Yet they are also a lost species of primitive humanity, clearly related to the Tasmanians, who in the previous century were regarded as possibly the lowest of peoples on the Social Darwinist ladder and hence as the 'missing link' between humans and apes (see Hulme 2000, p.136). Herbert's ape-men possess a language, a social organisation and a crude religion, ritually sacrificing white victims on the altar of an evil water spirit. Written on the eve of his first departure for Black Australia, 'The Ape-Men of Mobongu' projected his own unconscious horror of darkness and blind fear of the primitive.

Another notable ingredient of 'The Ape-Men of Mobongu' is its Boy's Own science. As the epithet implies, science was nothing new to children's fiction in the 1920s. Lian Goodall notes, for example, that one of the most popular subjects for children in the late Victorian age was natural history: 'The expansion of the British Empire, the increasing interest in natural history which was fueled by writings of Darwin and other scientists, and the development of middle class literacy-all converged to make natural history the subject of a vast number of factual and fictional works.' The explorer-hero was a specially favoured fictional device for 'feeding the natural scientific curiosity of children, while at the same time giving them more general information about the far reaches of the expanding British empire' (Goodall). Herbert was a pharmacist before he was a writer, and he splits the roles in two, with the explorer captive at the black heart of empire and the scientist as his saviour. Readers of this joumal will be better equipped than I to 
ponder the implications of this splitting of science and exploration for Herbert's conceptualising of Australian boyhood. Bush science is surely a key ingredient. But the intersecting trajectories in the story of these two roles also suggest something of Herbert's cultivation of the 'Astor' persona in relation to the decision to write the colonial adventure, in particular the way in which he projected himself onto the frontier, as a scientist or in other cases a civil engineer. The value ascribed to science underpins a tension in his writing (barely discernible in this story but rapidly evolving) between romance and realism, as he began to nurse a more serious literary ambition.

The bifurcation of the colonial adventure hero, explorer and scientist, anticipates to some degree the ironical selfimage that Herbert invests in Professor Orbitt and $\mathrm{Mr}$ Goborrow in Seven Emus (1959). Both are anthropologists, but one is an idealist and the other a swindler. Together they position the anthropologist as colonialist culturehero on the racial fault-line of national identity. Orbitt prophesies that people of Aboriginal blood will one day enjoy special status, because 'when the full-bloods have died out' the settler population, 'will be trying to find roots' that might allow them to identify with land and forge a sense of belonging. Goborrow adapts the theory to a scheme for defrauding Aboriginal people of their land rights and culture (1959, pp.122-3). Herbert revisits through Goborrow one of the under-examined themes of 'The Apes of Mobongu'-the looting of indigenous relics.

The story's captive is named in dubious honour of Herbert's literary mentor, Colin Wills, the first writer he met and in 1927 the closest thing he had to a friend. Wills was a sub-editor with Smith's Weekly who had previously worked as a junior reporter in the Police Department of the Daily' Guardian. He was impressive for having a nonliterary job and being frankly contemptuous of it. But he had also written reams of poetry, sketches and stories. He hated journalism, and aspired 'to better modes of literary expression'. He was just nineteen years of age. But Herbert was impressed by his superior literary knowledge, the high value he put on literature and by his sense of the literary calling. He was also impressed by the fact that, when he was only seventeen, Wills had had a poem published in Vision, Kenneth Slessor's and Jack Lindsay's modern art-magazine. But Wills's stated ambition was to be a novelist, and he discoursed wisely on all the latest intellectually fashionable fiction. In short, Wills was the epitome of cultured sophistication, and Herbert was a self-confessed literary primitive. ${ }^{7}$ Until now we have not been able to appreciate how he wrote himself out of debt to his mentor. In 'The Ape-Men of Mobongu' in fact he reverses that debt, rescuing Wills from the forces of primitivism that hold him enthralled and imperilled. We cannot know what Wills thought of this fiction. We do know what he thought later of Capricornia: it was written with an axe. After that comment, Wills was forever the enemy.

In old age, assaying his last grand fiction, he began with a strangely similar title, 'The Ape-Men of the Happy South Land'. (He later altered this to 'Billygoat Hill'.) Post-Whitlam politics seemed a lampoon of the Superman ideal. Herbert's ape-man was now the white man. Capricornia had prefigured the racial reversal of the metaphor some forty years earlier. The fatal flaw of the Ape-Men of the Happy South Land in the ' 80 s is essentially the same as that of Ned Krater, first Superman and Hairy Man of his first novel: the inability to control or transcend animal impulses, lack of civilisation, lack of humanity. What we see in 'The Ape-Men of Mobongu', a decade before Krater's prophecy of doom, is the unexamined primitivist metaphor at its first outing, with the white scientist tricking and triumphing over a lost and lesser race of offshore indigenes. 


\section{NOTES}

1. This story was 'North of Capricorn', and it appeared in the Australian Journal, 1 August 1925.

2. In Xavier Herbert, 'A Book Called Capricornia', unpublished typescript, copy in the author's possession.

3. In Pals it appears under the name of Herbert Aster [sic].

4. While Beatrice Grimshaw's Isles of Adventure: Experiences in Papua and Neighbouring Islands was not published until 1930, Herbert may have read of her historic journey up the Sepik in 1923. She was the first white woman to visit the area, travelling with missionary guides, and she witnessed their rescue of a young boy captured in a raid on a neighbouring village, who was allegedly being held for slaughter.

5. An extract from 'Giants of lron' appeared posthumously in Short Stories 1925-1934 by Xavier Herbert: South of Capricomia, pp.182-188. A longer extract from an untitled and incomplete novella, apparently written around the same time, also appears there, pp.189-289.

6. Herbert, interviewed by Iremonger et al, 13 December 1975, ANL Oral History Collection, TRC 397, 1:2/8.

7. Herbert, to L. H. Hergenhan, 15 May 1972, UQFL 203, Box 8.

8. As Kenneth Slessor lamented when reviewing George Blaikie's nostalgic history of Smith's Weekly in 1966 , Wills's name is generally absent from the star list of Smith's early days. Wills's expatriatism determined the tragedy of his career. He left Australia permanently in 1939, and published all of his major works (travel and autobiography mainly) in England, yet made little mark there and was soon forgotten in Australia also. He always aspired to be but never actually became a novelist, and his Rhymes of Sydney (1933) is undeservedly long out of print.

\section{REFERENCES}

Aster [sic], Herbert (later Herbert, Xavier) 'The Sea Vultures', in Pals: An Australian Paper for Australian Boys, 19 and 26 March, and 2 April 1927, repeated in R. McDougall (1990) (ed), Short Stories 1925-1934 by Xavier Herbert: Soult of Capricornia. Melbourne, pp. 133-81.

Astor, Herbert (later Herbert, Xavier) 'The ApeMen of Mobongu', The Boys Weekly, 24 June 1927.

Dixon, Robert (1995) Writing the Colonial Adventure: Race, Gender and Nation in Anglo-Australian Popular Fiction, 1875. 1914. Melbourne, Cambridge University Press.

Goodall, Lian, "'Zebros and elsophants" Images of blacks in natural history adventureempire tales read by young people in Wellington County. Ontario, 1880-1890', http://www.liangoodall.com/articles/ zebros_and_elsophants.html.

Herbert, Alfred (later Herbert, Xavier), 'North of Capricorn', in The Australian Journal, 1 August 1925, repeated in R. McDougall (1990) (ed), Short Stories 1925-1934 by Xavier Herbert: South of Capricomia. Melbourne, Oxford, pp.15-35.

Herbert, Xavier, 'A Book Called Capricornia', unpublished typescript.

Herbert, Xavier (1959) Seven Emus. Sydney, Angus and Robertson.

Hulme, Peter (2000) Remnants of Conquest: The Island Caribs and Their Visitors, 1877. 1998. Oxford, Oxford University Press.

Krauth, Nigel (1982) 'Introduction', New Guinea lmages in Australian Literature. St. Lucia, University of Queensland Press. 


\section{BIOGRAPHICAL NOTE}

Russell McDougall teaches Australian Literature at the University of New England, where he is Head of English, Communication \& Theatre. He has published widely on West African, Caribbean and Australian literatures. He edited South of Capricornia: Short Stories 1925 to 1934 by Xavier Herbert (Oxford, 1991) and is presently working with Peter Hulme on a book entitled In the Margins of Anthropology: Writing, Travel, Empire.

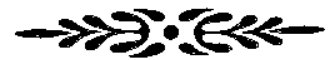

